\title{
Perbandingan Data Harian dan Data Bulanan pada Suhu Permukaan Laut di Samudera Hindia Menggunakan Partial Least Square-Structural Equation Modelling
}

\author{
Retno Wahyuni Putri ${ }^{1}$, Miftahuddin Miftahuddin' ${ }^{2 *}$ \\ 12 Jurusan Statistika, Fakultas MIPA, Universitas Syiah Kuala, \\ Jl. T. Nyak Arief No. 441 Kota Banda Aceh 23111, Indonesia \\ *Penulis Korespondensi. Email:miftah@unsyiah.ac.id
}

\begin{abstract}
ABSTRAK
Suhu permukaan laut (SPL) merupakan salah satu fitur variabilitas iklim yang memiliki peranan cukup besar terhadap aktivitas manusia. Penelitian ini bertujuan untuk memprediksi dan mengetahui apakah variabel cuaca dan iklim dengan indikator pengukurnya dapat memprediksi perubahan SPL dengan membandingkan pada data harian dan bulanan. Penelitian ini menggunakan pendekatan Partial Least Square-Strucural Equation Modelling (PLSSEM) yang dapat memprediksi hubungan kausalitas variabel laten eksogen dengan variabel laten endogen. Hasil yang diperoleh dari penelitian ini yaitu, dari sembilan indikator yang digunakan hanya terdapat 6 indikator yang signifikan dengan nilai loading factor $>0,7$ yaitu suhu permukaan laut $\left({ }^{\circ} \mathrm{C}\right)$ sebagai pengukur variabel laten Perubahan SPL, kecepatan angin $(\mathrm{m} / \mathrm{s})$ dan kelembaban relatif (\%) sebagai pengukur variabel laten cuaca, dan suhu udara $\left({ }^{\circ} \mathrm{C}\right)$, radiasi matahari gelombang pendek $\left(\mathrm{w} / \mathrm{m}^{2}\right)$ untuk data harian, dan radiasi matahari gelombang panjang $\left(\mathrm{w} / \mathrm{m}^{2}\right)$ untuk data bulanan sebagai pengukur variabel laten iklim. Inner model yang diperoleh pada data harian: Perubahan SPL $(\eta)=-0,285$ cuaca $+0,650 \mathrm{iklim}+\zeta$ dan pada data bulanan Perubahan SPL $(\eta)=-0,330$ cuaca $+0,793$ iklim $+\zeta$. Pada data bulanan variabel laten cuaca dan iklim beserta indikator pengukurnya memberikan pengaruh yang lebih besar terhadap perubahan SPL dengan nilai koefesien pada model yang didapatkan lebih besar dibandingkan pada data harian. Variabel laten yang bepengaruh signifikan terhadap perubahan SPL ialah cuaca dan iklim. Hal ini menunjukkan bahwa apabila terjadi peningkatan atau penurunan terhadap cuaca dan iklim dapat menyebabkan perubahan terhadap SPL secara signifikan. Nilai kriteria pada outer model dan inner model pada data harian dan bulanan didapatkan hasil yang lebih baik pada data bulanan.
\end{abstract}

\section{Kata Kunci:}

Suhu Permukaan Laut; Partial Least Square; Cuaca; Iklim; Outer Model; Inner Model

\section{ABSTRACT}

Sea surface temperature (SST) is one of the features of climate variability that has a significant role in human activities. This study aims to predict and determine whether weather and climate variables with their measuring indicators can predict changes in SST by comparing daily and monthly data. This study uses a partial least square-structural equation modeling (PLS-SEM) approach which can predict the causality relationship between exogenous latent variables and endogenous latent variables. The results obtained from this study are, from the nine indicators used there are only 6 significant indicators with a loading factor value $>0.7$, namely sea surface temperature (oC) as a measure of latent variables SST

e-ISSN: 2656-1344 (C) 2022 R. W. Putri, M. Miftahuddin | Under the license CC BY-NC 4.0

Received: 11 July 2021 | Accepted: 24 September 2021 |Online: 1 January 2022 
changes, wind speed $(\mathrm{m} / \mathrm{s})$ and humidity relative $(\%)$ as a measure of the latent variable of weather, and air temperature $(\mathrm{oC})$, short-wave solar radiation $(\mathrm{w} / \mathrm{m} 2)$ for daily data, and long-wave solar radiation $(w / m 2)$ for monthly data as a measure of climate latent variable. Inner model obtained on daily data: SST change $(\eta)=-0.285$ weather +0.650 climate + and on monthly data SST change $(\eta)=-0.330$ weather +0.793 climate + . In monthly data, weather and climate latent variables and their measuring indicators have a greater influence on changes in SST with the coefficient values in the model obtained being greater than in daily data. Latent variables that have a significant effect on changes in SST are weather and climate. This shows that if there is an increase or decrease in weather and climate it can cause significant changes to the SST. The value of the criteria on the outer model and inner model on daily and monthly data obtained better results on monthly data. The presence of more missing data in daily data can be one of the causes of this happening.

Keywords:

Sea Surface Temperature; Partial Least Square; Weather; Climate; Outer Model; Inner Model

Format Sitasi:

R. W. Putri and M. Miftahuddin, "Perbandingan Data Harian dan Data Bulanan pada Suhu Permukaan Laut di Samudera Hindia Menggunakan Partial Least Square-Structual Equation Modelling," Jambura J. Math., vol. 4, no. 1, pp.1-16, 2022, doi: https://doi.org/10.34312/jjom.v4i1.11191

\section{Pendahuluan}

Suhu Permukaan Laut (SPL) merupakan salah satu indikator penting dari sebuah wilayah. SPL di dunia bervariasi terutama yang terletak di garis lintang, dengan perairan yang paling hangat umumnya berada pada bagian khatulistiwa dan perairan terdingin di Antartika [1]. Penelitian ini mengkhususkan SPL yang diambil yaitu berada pada 1 meter di bawah permukaan laut dengan satu titik yang paling dekat dengan provinsi Aceh. Wilayah Indonesia paling barat adalah Pulau Weh di Provinsi Aceh yang berada di $6^{\circ} \mathrm{LU}$ dan samudera yang berdekatan dengan Provinsi Aceh adalah Samudera Hindia [2].

Lebih dari 2/3 bagian dari permukaan bumi merupakan lautan. Laut merupakan penyedia utama air tawar bagi makhluk hidup yang ada di daratan. Air tawar yang digunakan sehari-hari sebagian besar berasal dari hasil penguapan air laut. Dengan menggunakan energi panas radiasi matahari [3]. SPL berkaitan dengan pemanasan global (global warming). Meningkatnya temperatur global diperkirakan akan menyebabkan perubahan-perubahan yang lain seperti naiknya permukaan air laut [4]. Salah satu penelitian yang menganalisis data SPL, [5] menganalisis suhu permukaan laut untuk penentuan daerah potensi ikan menggunakan citra satelit modis level 1B menggunakan algoritma minnet 2001. Hasil dari penelitian ini menunjukkan bahwa pada bulan April 2012 dengan rentang suhu antara $20^{\circ} \mathrm{C}$ sampai $29,94^{\circ} \mathrm{C}$.

Suhu permukaan laut tentunya mengalami perubahan dari waktu ke waktu. Peningkatan dan penurunan suhu permukaan laut tersebut dapat disebabkan oleh kondisi meteorologis seperti keadaan cuaca dan iklim diantaranya adalah curah hujan, penguapan, kelembaban, suhu, kecepatan angin dan intensitas cahaya matahari. untuk mengetahui faktor apa yang lebih berperan secara signifikan terhadap perubahan suhu permukaan laut dan untuk mengantisipasi terjadinya perubahan suhu permukaan laut maka perlu dilakukan estimasi terhadap suhu permukaan laut tersebut.

Data yang digunakan dalam penelitian ini merupakan data time series yang dapat digunakan untuk melihat pola data pada masa lalu untuk melihat pola data pada masa 
yang akan datang. Jumlah sampel pada penelitian ini adalah sampel kecil dan terdapat data hilang dengan periode harian dan bulanan. Analisis yang mengkaji data time series dengan jumlah sampel kecil dapat diatasi menggunakan pendekatan partial least square (PLS). PLS merupakan alternatif dari structural equation modelling (SEM) yang masih mengharuskan terdapat asumsi. SEM dapat digolongkan menjadi dua jenis, yaitu SEM berbasis kovarian atau covarianve based structural equation modeling (CB-SEM) dan SEM berbasis varians atau variance based structural equation modeling (VB-SEM). SEM yang berbasis varian meliputi Partial Least Square (PLS) yang merupakan pemodelan bebas asumsi sebaran dari variabel pengamatan [6]. PLS merupakan pemodelan dengan mengambil kesimpulan dari uji signifikansi untuk mengetahui dan memprediksi variabel laten eksogen yang berpengaruh terhadap variabel laten endogen dan signifikansi indikator terhadap variabel latennya tanpa perlu melakukan uji asumsi. Penelitian ini juga menggunakan algoritma Nonlinear Iterative Partial Least Squares (NIPALS) dalam estimasi parameter dengan tahapan iterasi untuk membentuk outer model dan inner model yang dibentuk berdasarkan indikator yang sudah valid dalam mengukur variabel laten.

\section{Metode}

Data dalam penelitian ini merupakan data sekunder yang didapatkan dari National Oceanic and Atmospheric Administration (NOAA). Data yang digunakan yaitu data harian dan bulanan dengan posisi titik $8^{\circ} \mathrm{N} 90^{\circ} \mathrm{E}$ yaitu satu titik yang dekat dengan Provinsi Aceh. Terdapat tiga variabel laten yaitu perubahan SPL sebagai variabel laten endogen dan variabel laten eksogen yaitu cuaca dan iklim dengan masing-masing memiliki tiga indikator. Data diambil mulai dari 01 Januari 2012 s.d 21 Februari 2020 dan terdapat beberapa data hilang pada masing-masing variabelnya. Adapun variabel yang digunakan seperti yang ditunjukkan pada Tabel 1.

Tabel 1. Variabel yang digunakan

\begin{tabular}{|c|c|c|c|c|c|c|c|}
\hline \multirow{2}{*}{$\begin{array}{l}\text { Variabel } \\
\text { laten }\end{array}$} & \multirow{2}{*}{\multicolumn{2}{|c|}{ Variabel Indikator }} & \multirow{2}{*}{ Satuan } & \multicolumn{2}{|c|}{ Jumlah observasi } & \multicolumn{2}{|c|}{ Jumlah data hilang } \\
\hline & & & & Harian & Bulanan & Harian & Bulanan \\
\hline \multirow{3}{*}{ 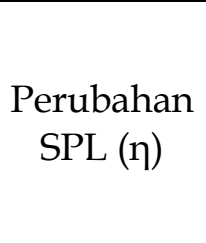 } & $\mathrm{Y}_{1}$ & $\begin{array}{l}\text { Suhu Permukaan } \\
\text { Laut }\end{array}$ & ${ }^{\circ} \mathrm{C}$ & 1513 & 52 & 1 & 4 \\
\hline & $\mathrm{Y}_{2}$ & Salinitas & $\%$ & 1142 & 40 & 372 & 16 \\
\hline & $\mathrm{Y}_{3}$ & $\begin{array}{l}\text { Temperatur bawah } \\
\text { laut }\end{array}$ & ${ }^{\circ} \mathrm{C}$ & 1408 & 47 & 106 & 9 \\
\hline \multirow{4}{*}{ Cuaca $\left(\xi_{1}\right)$} & $\mathrm{X}_{1}$ & Curah Hujan & $\mathrm{mm}$ & 863 & 29 & 651 & 27 \\
\hline & $\mathrm{X}_{2}$ & Kecepatan angin & $\mathrm{m} / \mathrm{s}$ & 1494 & 51 & 20 & 5 \\
\hline & $X_{3}$ & Kelembaban relatif & $\%$ & 1505 & 51 & 9 & 5 \\
\hline & $\mathrm{X}_{4}$ & Suhu Udara & ${ }^{\circ} \mathrm{C}$ & 1505 & 51 & 9 & 5 \\
\hline \multirow{2}{*}{$\operatorname{Iklim}\left(\xi_{2}\right)$} & $X_{5}$ & $\begin{array}{l}\text { Radiasi matahari } \\
\text { gelombang pendek }\end{array}$ & $\mathrm{w} / \mathrm{m}^{2}$ & 1504 & 52 & 10 & 4 \\
\hline & $\mathrm{X}_{6}$ & $\begin{array}{l}\text { Radiasi matahari } \\
\text { gelombang } \\
\text { panjang }\end{array}$ & $\mathrm{w} / \mathrm{m}^{2}$ & 1514 & 56 & 0 & 0 \\
\hline
\end{tabular}

Analisa data menggunakan metode PLS yang merupakan alternatif dari SEM. 


\subsection{Structual Equation Modelling (SEM)}

Sructural Equation Modeling (SEM) merupakan analisis multivariate yang digunakan untuk menggambarkan kekuatan hubungan linier antara indikator dan variabel laten. Tipe variabel laten dalam SEM terbagi menjadi dua yaitu endogen ( $\eta$ ) dan eksogen ( $)$. SEM terbagi menjadi dua, yaitu SEM berbasis kovarian atau covarianve based structural equation modeling (CB-SEM) dan SEM berbasis varians atau variance based structural equation modeling (VB-SEM). SEM yang berbasis varian meliputi Partial Least Square (PLS). Kedua jenis SEM ini memiliki perbedaab yang terletak pada penggunaannya. SEM berbasis kovarians bertujuan untuk mengestimasi model dalam pengujian atau konfirmasi teori, sedangkan SEM berbasis varians bertujuan memprediksikan model untuk pengembangan teori [6].

\subsection{Partial Least Square (PLS)}

PLS ialah suatu pendekatan model dengan hubungan sebab akibat yang memiliki tujuan untuk memaksimalkan variansi dari variabel laten endogensehingga mampu dijelaskan (explained variance) oleh variabel laten eksogen. Partial Least Squares menurut Hijarah et. al [7] dapat mengatasi persoalan yaitu solusi yang tidak dapat diterima (inadmissible solution), yaitu masalah matriks singular tidak akan pernah terjadi. Masalah un-identified, under-identified atau over-identified yang tidak akan mungkin terjadi karena PLS berfungsi pada model struktural yang bersifat rekursif. Beigitu juga pada masalah faktor yang tidak dapat ditentukan (factor indeterminacy), karena variabel laten ialah kombinasi liniar dari indikator-indikator, maka selalu akan diperoleh variabel laten yang bersifat gabungan.PLS dapat diterapkan dalam model pengukuran reflektif maupun formatif [8]. Terdapatdua persamaan pada PLS yang meliputi persamaan pada model struktural (inner model) dan persamaan pada model pengukuran (outer model) yang diperoleh melalui tahapan iterasi dalam estimasi parameternya [9].

Persamaan PLS meliputi persamaan pada model struktural (inner model) dengan persamaan:

$$
\eta_{j}=\beta_{j i} \eta_{i}+\gamma_{j b} \xi_{b}+\zeta_{j}
$$

dimana, $\beta_{j i}$ : koefisien jalur yang menghubungkan prediktor endogen ke-ji, $\gamma_{j b}$ : koefisien jalur yang menghubungkan prediktor eksogen ke- $j b, \zeta_{j}$ : inner residual variabel ke- $j, \xi_{b}$ : variabel laten eksogen ke- $b$, dan $\eta_{j}$ : variabel laten endogen ke- $j$. Sedangkan model pengukuran (outer model) pada variabel eksogen dan endogen yang dirumuskan sebagai berikut:

$$
\begin{gathered}
x_{q}=\lambda_{x q} \xi_{q}+\delta_{q} \text { dan, } \\
y_{p}=\lambda_{y p} \eta_{p}+\varepsilon_{p}
\end{gathered}
$$

dimana, $x_{q}, y_{p}$ : variabel eksogen ke- $q, \lambda_{x q}$ : bobot koefesien regresi dari variabel eksogen ke- $q, \xi_{q}$ : variabel laten dari variabel eksogen ke- $q, \delta_{q}$ : kesalahan (error) pengukuran ke$q$, dan $y_{p}$ : variabel endogen ke- $p, \lambda_{y p}$ : bobot koefesien regresi variabel endogen dari $\eta$ ke- $p, \eta_{p}$ : variabel laten dari endogen ke- $p, \varepsilon_{p}$ : kesalahan (error) pengukuran ke $p$.

Estimasi pada model PLS dilakukan dengan metode kuadrat terkecil (least square) dengan algoritma NonLinier Iterative Partial Least Square (NIPALS). Proses penghitungan 
dilakukan melalui iterasi. Teknik iterasi yang dilakukan dalam PLS terdiri dari tiga tahap [9], sebagai berikut:

a. Iterasi pertama menghasilkan estimasi bobot (weight estimate) dan digunakan untuk menghasilkan skor (score factor) pada variabel laten.

b. Iterasi kedua menghasilkan estimasi jalur (path estimate) yang mencerminkan bobot (weight) kontribusi variasi perubahan variabel laten eksogen terhadap variabel laten endogen. Bobot tersebut menghasilkan nilai $R^{2}$ yang muncul pada variabel laten endogen. Nilai estimasi yang dihasilkan meliputi nilai koefisien beta $(\beta)$ dan gamma $(\gamma)$. Selain itu, dihasilkan estimasi loading factor, yaitu lambda $(\lambda)$ yang merupakan koefisien dari outer model.

c. Iterasi ketiga menghasilkan skor estimasi rata-rata (mean) dan lokasi parameter (parameter location/konstanta regresi) untuk indikator dan variabel laten.

Metode dan prosedur analisis pada penelitian ini digunakan sebagai kerangka dalam proses pengerjaan penelitian. Analisis data dilakukan menggunakan software SmartPLS 3.0. Adapun prosedur dan tahapan analisis data dalam penelitian ini adalah:

a. Identifikasi awal yang dilakukan yaitu analisis statistika deskriptif untuk melihat karakteristik dan gambaran awal dari setiap variabel data yang disajikan dalam bentuk, ringkasan statistik dan pemeriksaan multikolinearitas.

b. Analisis inferensia, dilakukan untuk mengetahui hubungan variabel laten eksogen terhadap variabel laten endogen menggunakan model regresi PLS dan mengestimasi parameter dari model dengan tahapan iterasi menggunakan algoritma NIPALS yaitu:

1) Merancang model dengan membentuk outer model dan inner model berdasarkan kajian teori dan telaah pustaka,

2) Menggambar diagram jalur (path diagram),

3) Mengkonversi diagram jalur ke dalam sistem persamaan,

4) Mengestimasi parameter model PLS, yaitu weight estimate, path estimate, dan lokasi parameter (parameter location) dengan menggunakan algoritma NIPALS.

5) Mendapatkan nilai skor faktor dari model.

6) Mengevaluasi outer model

Evaluasi outer modeldilakukan untuk menggambarkan bagaimana indikator merepresentasikan variabel latennya, dengan menguji validitas dan reliabilitasnya. Jika indikator dan blok indikator telah valid dan reliabel dilanjutkan dengan mengevaluasi inner model.

7) Jika tidak, kembali mengkonstruksi diagram jalur.

8) Mengevaluasi inner model dilakukan untuk menggambarkan hubungan antar variabel laten yang dilakukan dengan menggunakan $R$-square, $f$-square, $Q$-square, Goodness of Fit index (GoF).

9) Pengujian hipotesis dilakukan dengan metode nonparametrik menggunakan uji statistik $t$ melalui prosedur bootstrapping dengan subsample sebesar 56 observasi dengan perulangan 100 kali.

10) Menarik kesimpulan dari hasil dan pembahasan yang telah dilakukan.

\subsection{Boostrapping}

Partial Least Square tidak mengasumsikan data menyebar normal ganda sehingga pengujian hipotesis secara parametrik tidak dapat dilakukan. Prosedur resampling bootsrapping yang merupakan teknik resampling nonparametrik, menjadi alternatif dalam melakukan pengujian hipotesisnya (Hair et al. 2011). Hipotesis statistik untuk inner model 
adalah $\mathrm{H}_{0}: \gamma_{\mathrm{i}}=0$ (variabel eksogen ke- $i$ tidak signifikan) dan $\mathrm{H}_{1}: \gamma_{\mathrm{i}} \neq 0$ (variabel eksogen ke-i signifikan) sedangkan hipotesis untuk outer model adalah $\mathrm{H}_{0}: \lambda_{i}=0$ (indikator ke- $i$ tidak signifikan) dan $\mathrm{H}_{1}: \lambda_{i} \neq 0$ (indikator ke-i signifikan).

\section{Hasil dan Pembahasan}

\subsection{Analisis Deskriptif Data}

Ringkasan statistik untuk data harian dan bulanan dataset SPL dapat dilihat pada Tabel 2 dan 3.

Tabel 2. Ringkasan Statistik Data Harian tahun 2012-2020

\begin{tabular}{ccccccccc}
\hline Variabel & Missing & Mean & Median & Min & Maks & $\begin{array}{c}\text { Standard } \\
\text { Deviation }\end{array}$ & $\begin{array}{c}\text { Quartil } \\
1\end{array}$ & $\begin{array}{c}\text { Quartil } \\
3\end{array}$ \\
\hline $\mathrm{Y}_{1}$ & 1 & 29,17 & 29,01 & 27,9 & 31,98 & 0,74 & 28,64 & 29,52 \\
$\mathrm{Y}_{2}$ & 372 & 33,55 & 33,53 & 32,2 & 34,76 & 0,47 & 33,24 & 33,92 \\
$\mathrm{Y}_{3}$ & 106 & 21,80 & 21,92 & 17,0 & 28,32 & 2,25 & 20,09 & 23,43 \\
$\mathrm{X}_{1}$ & 651 & 0,13 & 0,00 & 0,00 & 4,43 & 0,38 & 0,00 & 0,01 \\
$\mathrm{X}_{2}$ & 20 & 5,69 & 5,90 & 0,00 & 11,4 & 2,39 & 3,9 & 7,5 \\
$\mathrm{X}_{3}$ & 9 & 79,36 & 79,9 & 58,7 & 94 & 4,66 & 76,8 & 82,5 \\
$\mathrm{X}_{4}$ & 9 & 28,45 & 28,4 & 26 & 31,1 & 0,80 & 27,9 & 28,9 \\
$\mathrm{X}_{5}$ & 10 & 223,24 & 242,3 & 7,4 & 323,6 & 66,05 & 190,1 & 271 \\
$\mathrm{X}_{6}$ & 0 & 415,39 & 422,7 & 350,3 & 457,4 & 26,19 & 393,9 & 437,6 \\
\hline
\end{tabular}

Tabel 3. Ringkasan statistik data bulanan tahun 2012-2020

\begin{tabular}{ccccccccc}
\hline Variabel & Missing & Mean & Median & Min & Max & $\begin{array}{c}\text { Standard } \\
\text { Deviation }\end{array}$ & $\begin{array}{c}\text { Kuartil } \\
1\end{array}$ & $\begin{array}{c}\text { Kuartil } \\
3\end{array}$ \\
\hline $\mathrm{Y}_{1}$ & 4 & 29,04 & 29,03 & 26,2 & 31,1 & 0,90 & 28,59 & 29,46 \\
$\mathrm{Y}_{2}$ & 16 & 33,52 & 33,55 & 32,59 & 34,32 & 0,42 & 33,3 & 33,71 \\
$\mathrm{Y}_{3}$ & 9 & 21,89 & 22,28 & 17,82 & 25,29 & 2,07 & 20,43 & 23,33 \\
$\mathrm{X}_{1}$ & 27 & 0,13 & 0,10 & 0,00 & 0,51 & 0,12 & 0,03 & 0,19 \\
$\mathrm{X}_{2}$ & 5 & 5,71 & 5,90 & 2,50 & 9,20 & 1,69 & 4,45 & 6,70 \\
$\mathrm{X}_{3}$ & 5 & 79,29 & 79,79 & 73,17 & 84,13 & 2,82 & 77,39 & 81,28 \\
$\mathrm{X}_{4}$ & 5 & 28,41 & 28,27 & 27,46 & 30,31 & 0,66 & 27,91 & 28,77 \\
$\mathrm{X}_{5}$ & 4 & 224,7 & 226,3 & 169,1 & 284,0 & 30,98 & 202,4 & 248,9 \\
$\mathrm{X}_{6}$ & 0 & 413,8 & 419,69 & 369,6 & 444,89 & 24,39 & 391,4 & 435,9 \\
\hline
\end{tabular}

Tabel 2 menunjukkan ringkasan statistik dari data harian pada 2012-2020 dimana pada setiap variabel terdapat data hilang. suhu permukaan laut memiliki 1 hari data yang tidak tercatat dengan suhu permukaan laut terendah sebesar $27,9 \circ \mathrm{C}$, dengan suhu permukaan laut maksimum sebesar $31,98^{\circ} \mathrm{C}$. Salinitas terdapat 372 hari data yang tidak tercatat dengan salinitas terendah adalah 32,2\%, dan maksimum sebesar $34,76 \%$. Temperatur bawah laut terdapat 106 hari data tidak tercatat, dengan temperatur terendah $17,09{ }^{\circ} \mathrm{C}$, rata-rata temperatur $21,80^{\circ} \mathrm{C}$ dan temperatur tertinggi sebesar $28,32^{\circ} \mathrm{C}$. Curah hujan memiliki jumlah data tidak tercatat terbanyak yaitu 651 hari, dengan curah hujan terendah sebesar $0 \mathrm{~mm}$ (tidak terjadi hujan), dan curah hujan tertinggi sebesar $4,43 \mathrm{~mm}$. kecepatan angin terdapat 20 hari data tidak tercatat, memiliki kecepatan angin maksimal sebesar $11,4 \mathrm{~m} / \mathrm{s}$. Kelembaban relatf memiliki 9 hari data tidak tercatat, 
dengan kelembaban relatif terendah sebesar 58,7\% dan kelembaban relatif tertinggi sebesar $94 \%$. Suhu udara terdapat 9 hari data tidak tercatat, dengan suhu udara terendah adalah $26^{\circ} \mathrm{C}$, dan suhu udara tertinggi yaitu $31,1^{\circ} \mathrm{C}$ (masih dalam batasan normal). Radiasi matahari gelombang pendek memiliki 10 hari data tidak tercatat, dengan radiasi terendah sebesar $7,4 \mathrm{w} / \mathrm{m}^{2}$ dan radiasi tertinggi sebesar $323,6 \mathrm{w} / \mathrm{m}^{2}$. Radiasi matahari gelombang panjang memiliki data yang lengkap, dengan radiasi terendah sebesar $350,3 \mathrm{w} / \mathrm{m}^{2}$, dan tertinggi sebesar $457,4 \mathrm{w} / \mathrm{m}^{2}$.

Tabel 3 menunjukkan ringkasan statistik dari data bulanan pada 2012-2020 dimana pada setiap variabel terdapat data hilang. suhu permukaan laut memiliki 4 bulan data yang tidak tercatat dengan suhu permukaan laut terendah sebesar $26,2^{\circ} \mathrm{C}$, dengan suhu permukaan laut maksimum sebesar $31,1^{\circ} \mathrm{C}$. Salinitas terdapat 16 bulan data yang tidak tercatat dengan salinitas terendah adalah $32,56 \%$, rata-rata salinitas air laut sebesar $33,56 \%$ dan maksimum sebesar 34,33\%. Temperatur bawah laut terdapat 9 bulan data tidak tercatat, dengan temperatur terendah $17,82^{\circ} \mathrm{C}$, rata-rata temperatur $21,89^{\circ} \mathrm{C}$ dan temperatur tertinggi sebesar $25,29 \circ \mathrm{C}$. Curah hujan memiliki jumlah data tidak tercatat terbanyak yaitu 27 bulan, dengan curah hujan terendah sebesar $0 \mathrm{~mm}$ (tidak terjadi hujan), dan curah hujan tertinggi sebesar $0,51 \mathrm{~mm}$. kecepatan angin terdapat 5 bulan data tidak tercatat, memiliki kecepatan angin terendah sebesar 2,5m/s, dengan kecepatan maksimal sebesar 9,2m/s. Kelembaban relatif memiliki 5 bulan data tidak tercatat, dengan kelembaban relatif terendah sebesar $73,17 \%$ dan kelembaban relatif tertinggi sebesar $84,13 \%$. Suhu udara terdapat 5 bulan data tidak tercatat, dengan suhu udara terendah adalah $27,46^{\circ} \mathrm{C}$, dan suhu udara tertinggi yaitu 30,31 ${ }^{\circ} \mathrm{C}$ (masih dalam batasan normal). Radiasi matahari gelombang pendek memiliki 4 bulan data tidak tercatat, dengan radiasi terendah sebesar 169,18w/ $\mathrm{m}^{2}$ dan radiasi tertinggi sebesar 284,04 w/ m². Radiasi matahari gelombang panjang memiliki data yang lengkap, dengan radiasi terendah sebesar $369,6 \mathrm{w} / \mathrm{m}^{2}$, dan tertinggi sebesar $444,89 \mathrm{w} / \mathrm{m}^{2}$. Selanjutnya, diberikan Boxplot data harian dan bulanan masing-masing pada Gambar 1 dan Gambar 2.
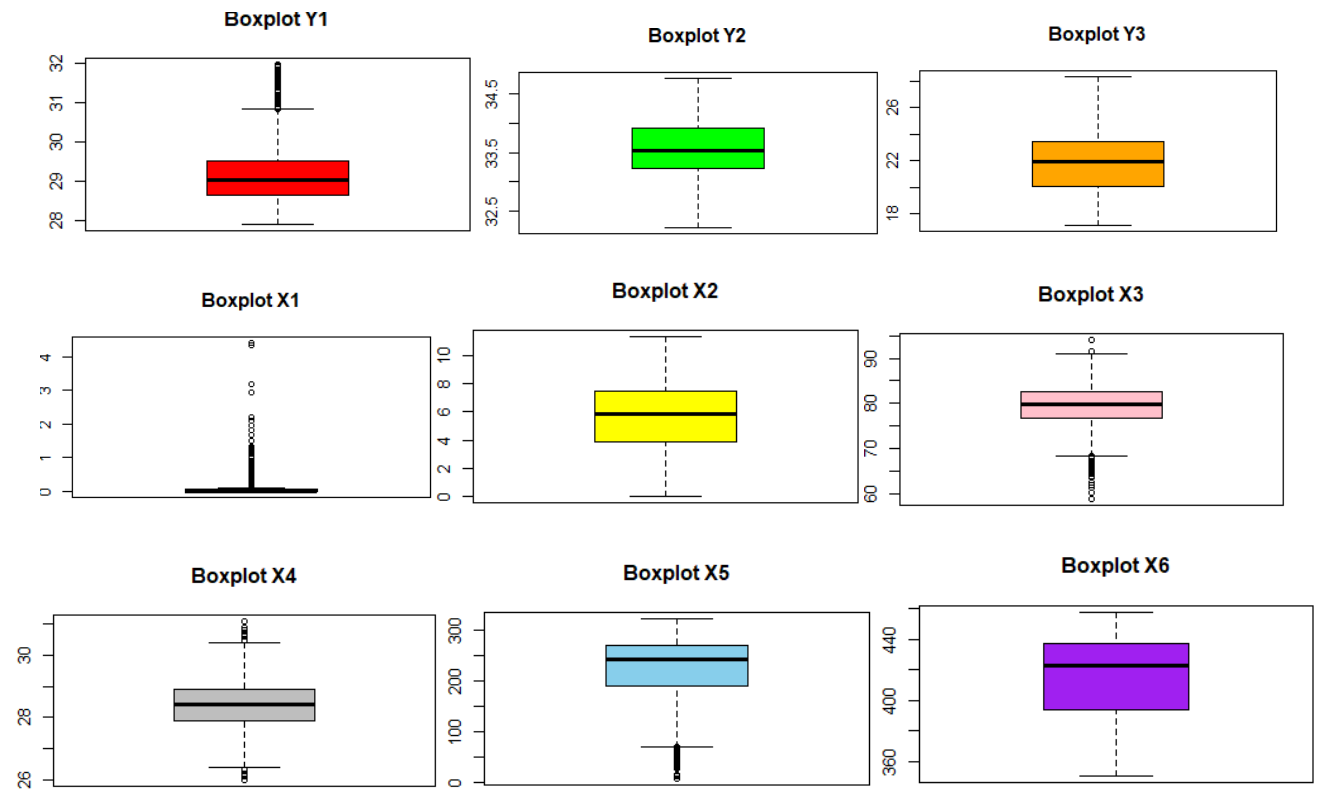

Gambar 1. Boxplot data harian 

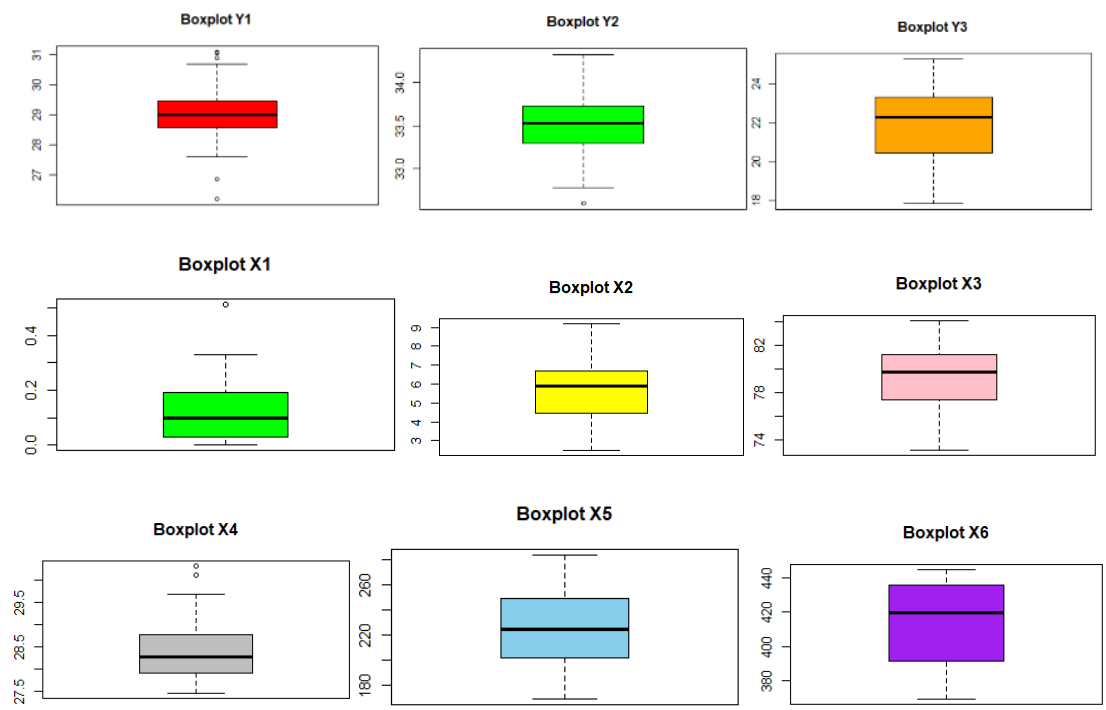

Gambar 2. Boxplot data bulanan

Gambar 1 dan Gambar 2 menunjukkan boxplot dari masing-masing variabel pada data harian dan data bulanan, terdapat outlier atas dan bawah pada kedua data. Adanya outlier dapat menyebabkan ketidak normalan pada data. Pada data harian diketahui terdapat outlier pada variabel $Y_{1}$ (suhu permukaan laut), $X_{1}$ (curah hujan), $X_{3}$ (kelembaban relatif), $X_{4}$ (suhu udara), dan $X_{5}$ (radiasi matahari gelombang panjang). Outlier pada data harian berada pada variabel $Y_{1}$ (suhu permukaan laut), $Y_{2}$ (salinitas), $X_{1}$ (curah hujan), $\mathrm{X}_{4}$ (suhu udara). Jumlah outlier lebih banyak terdapat pada data harian, dengan outlier paling banyak berada pada variabel $X_{1}$ (curah hujan). Hal ini juga dapat terjadi karena jumlah observasi yang digunakan pada data harian lebih banyak dibandingkan pada data bulanan.

\subsection{Analisis Partial Least Square}

Analisis pada SEM-PLS dilakukan dengan langkah-langkah yang terdiri dari konseptualisasi model, mengevaluasi model dan terakhir melakukan pengujian hipotesis.

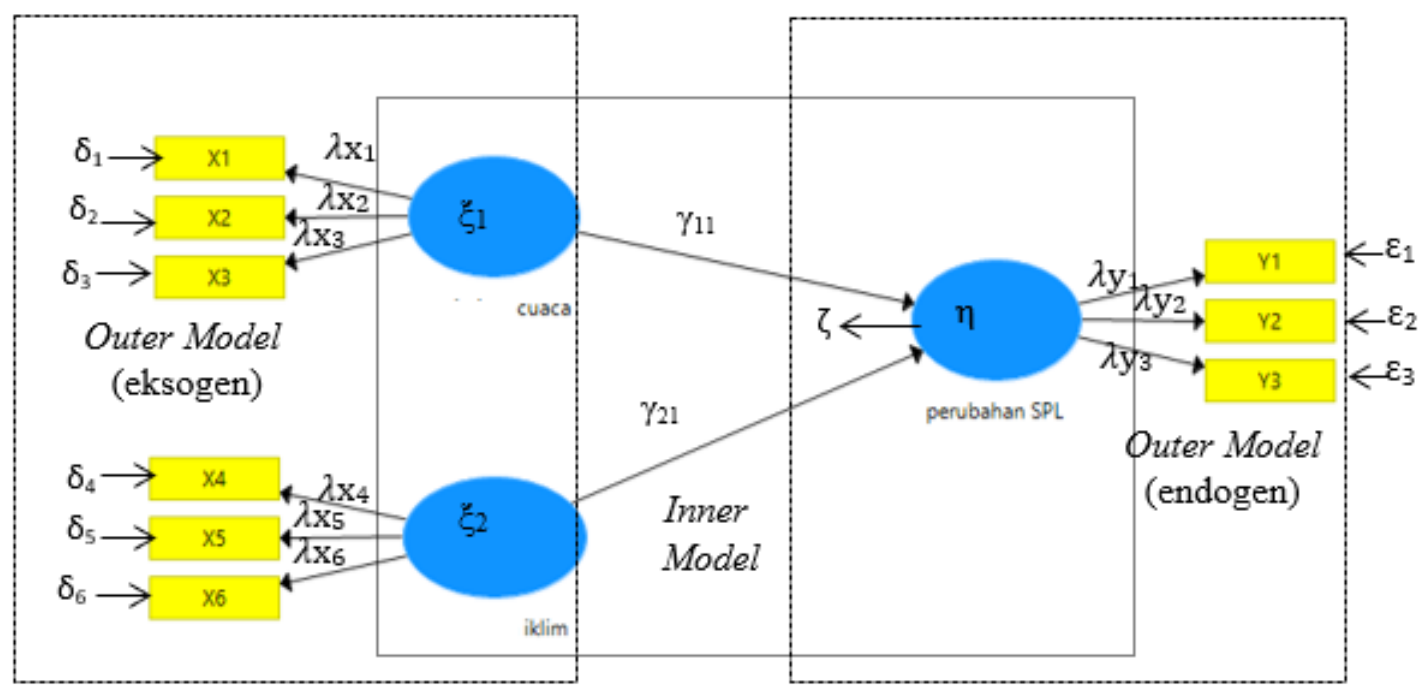

Gambar 3. Diagram jalur awal. 


\subsubsection{Konseptualisasi Model}

Konseptualisasi model dilakukan dengan indikator bersifat refleksif. Artinya perubahan pada indikator tidak menyebabkan perubahan pada variabel laten yang merupakan hasil pencerminan dari indikatornya. Kemudian mengktronsuksi model kedalam diagram jalur yang selanjutnya dikonversikan kedalam sistem persamaan. Diagram jalur menunjukkan hubungan dari indikator-indikator terhadap variabel latennya.

Diagram jalur awal dan notasi PLS seperti digambarkan oleh Hijrah et. al [7] pada Gambar 3. Selanjutnya adalah mengkonfersi diagram jalur kedalam sistem persamaan, sesuai dengan model-model yang terdapat di dalam diagram jalur, yaitu:

\section{Outer Model}

$\mathrm{X}_{1}=\lambda \mathrm{x}_{1} \xi_{1}+\delta_{1} \mathrm{X}_{4}=\lambda \mathrm{x}_{4} \xi_{2}+\delta_{4} \quad \mathrm{Y}_{1}=\lambda_{\mathrm{y} 1} \eta_{1}+\varepsilon_{1}$

$X_{2}=\lambda x_{2} \xi_{1}+\delta_{2} X_{5}=\lambda x_{5} \xi_{2}+\delta_{5} \quad Y_{2}=\lambda_{y_{2}} \eta_{1}+\varepsilon_{2}$

$X_{3}=\lambda x_{3} \xi_{1}+\delta_{3} X_{6}=\lambda x_{6} \xi_{2}+\delta_{6} \quad Y_{3}=\lambda_{y_{3}} \eta_{1}+\varepsilon_{3}$

\section{Inner Model}

$\eta_{1}=\gamma_{11} \xi_{1}+\gamma_{21} \xi_{2}++\zeta_{1}$

Adapun perbandingan outer model pada dataset SPL harian dan bulanan disajikan pada Tabel 4.

Tabel 4. Outer Model pada dataset SPL

\begin{tabular}{cc}
\hline Data Harian: Eksogen & Endogen \\
\hline $\mathrm{X}_{2}=0,874$ Cuaca $+\delta_{2}$ & $\mathrm{Y}_{1}=1$ suhu permukaan laut $+\varepsilon_{1}$ \\
$\mathrm{X}_{3}=0,776$ Cuaca $+\delta_{3}$ & \\
$\mathrm{X}_{4}=0,974$ Iklim $+\delta_{4}$ & \\
$\mathrm{X}_{5}=0,587$ Iklim $+\delta_{5}$ & \\
\hline Data Bulanan: Eksogen & \\
\hline $\mathrm{X}_{2}=0,913$ Cuaca $+\delta_{2}$ & $\mathrm{Y}_{1}=1$ Perubahan SPL $+\varepsilon_{1}$ \\
$\mathrm{X}_{3}=0,853$ Cuaca $+\delta_{3}$ & \\
$\mathrm{X}_{4}=0,929$ Iklim $+\delta_{4}$ & \\
$\mathrm{X}_{6}=0,787$ Iklim $+\delta_{5}$ & \\
\hline
\end{tabular}

\subsubsection{Evaluasi Outer Model}

Evaluasi Outer model dilakukan untuk memverifikasi indikator dan variabel laten yang dapat diuji berdasarkan uji validitas dan uji reliabilitas. Uji validitas dilakukan dengan melihat signifikansi dari nilai loading factor, AVE, dan validitas diskriminan. Sedangkan uji reliabilitas dengan melihat nilai dari composite reability.

Pada validitas konvergen dapat dilihat bagaimana indikator-indikator dari suatu variabel laten membentuk kontruksnya. Validitas konvergen dapat dilihat berdasarkan nilai loading factor dan Average Variance Extracted (AVE). Loading factor merupakan suatu nilai yang menunjukkan berapa besarnya variansi yang dapat dijelaskan oleh variabel 
laten. Pada indicator reliability, suatu indikator harus dieliminasi dari model pengukuran ketika nilai loading factor $(\lambda)<0,5[10]$.

Nilai loading factor pada data dapat dilihat pada Tabel 3 berikut, baik pada data harian maupun pada data bulanan. Nilai loading factor awal yang diperoleh masih terdapat beberapa indikator yang nilainya $<0,5$, yaitu $Y_{2}, Y_{3}$ pada variabel laten perubahan SPL, indikator $X_{1}$ pada variabel laten cuaca dan indikator $X_{6}$ pada variabel laten iklim untuk data harian dan indikator $X_{5}$ pada data bulanan. Maka indikator tersebut harus dieliminasi dan dilakukan iterasi ulang dengan indikator yang tidak memenuhi kriteria tersebut di eliminasi [12]. Selanjutnya, nilai Loading Factor data diberikan pada Tabel 5.

Tabel 5. Nilai Loading Factor data

\begin{tabular}{|c|c|c|c|}
\hline \multicolumn{4}{|c|}{ Nilai Loading Factor awal } \\
\hline Variabel Laten & Indikator & $\begin{array}{l}\text { Data } \\
\text { Harian }\end{array}$ & Data Bulanan \\
\hline \multirow{4}{*}{$\begin{array}{l}\text { Perubahan } \\
\text { SPL }\end{array}$} & Suhu permukaan laut & 0,921 & 0,889 \\
\hline & Salinitas & $-0,330$ & $-0,495$ \\
\hline & Temperatur bawah laut & $-0,643$ & $-0,735$ \\
\hline & Curah hujan & 0,196 & 0,127 \\
\hline \multirow[t]{3}{*}{ Cuaca } & Kecepatan angin & 0,877 & 0,927 \\
\hline & Kelembaban relatif & 0,753 & 0,817 \\
\hline & Suhu udara & 0,974 & 0,938 \\
\hline \multirow[t]{2}{*}{ Iklim } & Radiasi gelombang pendek & 0,538 & 0,397 \\
\hline & Radiasi gelombang panjang & 0,403 & 0,705 \\
\hline \multicolumn{4}{|c|}{ Nilai Loading Factor setelah eliminasi indikator } \\
\hline Variabel Laten & Indikator & $\begin{array}{l}\text { Data } \\
\text { Harian }\end{array}$ & Data Bulanan \\
\hline $\begin{array}{l}\text { Perubahan } \\
\text { SPL }\end{array}$ & Suhu permukaan laut & 1 & 1 \\
\hline \multirow{3}{*}{ Cuaca } & Kecepatan angin & 0,874 & 0,913 \\
\hline & Kelembaban relatif & 0,766 & 0,853 \\
\hline & Suhu udara & 0,974 & 0,929 \\
\hline \multirow[t]{2}{*}{ Iklim } & Radiasi gelombang pendek & 0,587 & - \\
\hline & Radiasi gelombang panjang & - & 0,787 \\
\hline
\end{tabular}

Nilai loading factor yang didapatkan setelah dilakukan eliminasi, sudah memenuhi kriteria karena nilainya $>0,7$, sehingga indikator pengukur yang ditetapkan sudah baik. Setelah didapatkan nilai loading factor yang valid maka selanjutnya adalah melihat nilai Average Variance Extracted (AVE). Nilai Average Variance Extracted (AVE) disajikan pada Tabel 6.

Tabel 6. Nilai Average Variance Extracted (AVE) sebelum dan sesudah eliminasi

\begin{tabular}{lcccc}
\hline \multirow{2}{*}{ Variabel } & \multicolumn{2}{c}{ Data Harian } & \multicolumn{2}{c}{ Data Bulanan } \\
\cline { 2 - 5 } & Sebelum & Sesudah & Sebelum & Sesudah \\
\hline Perubahan SPL & 0,457 & 1 & 0,514 & 1 \\
Cuaca & 0,458 & 0,676 & 0,512 & 0,781 \\
Iklim & 0,467 & 0,647 & 0,525 & 0,741 \\
\hline
\end{tabular}


Setelah dilakukan eliminasi terhadap beberapa indikator terlihat pada Tabel 6, dari ketiga variabel laten memiliki nilai AVE menandakan indikator memiliki nilai validitas konvergen yang baik [13]. Oleh karena itu, ukuran convergent validity sudah baik, sehingga indikator suhu permukaan laut dapat mengukur perubahan SPL, kecepatan angin dan kelembaban relatif dapat mengukur variabel laten cuaca serta indikator suhu udara dan radiasi matahari gelombang pendek untuk data harian dan radiasi matahari gelombang panjang untuk data bulanan dapat mengukur varibael laten iklim. Nilai AVE yang diperoleh pada data bulanan lebih tinggi dibandingkan dengan data harian. Kriteria selanjutnya adalah validitas diskriminan yang dilihat dengan membandingan korelasi antar variabel laten dengan akar AVE nya. Berikut disajikan nilai akar AVE data harian dan bulanan, masing-masing pada Tabel 7 dan Tabel 8.

Tabel 7. Nilai akar AVE data harian

\begin{tabular}{lccc}
\hline \multicolumn{4}{c}{ Sebelum dieliminasi } \\
\hline Variabel & Perubahan SPL & Cuaca & Iklim \\
Perubahan SPL & $\mathbf{0 , 6 7 6}$ & & \\
Cuaca & $-0,386$ & $\mathbf{0 , 6 7 7}$ & \\
Iklim & 0,658 & $-0,105$ & $\mathbf{0 , 6 8 3}$ \\
\hline \multicolumn{4}{c}{} \\
\hline Variabel & Setelah dieliminasi & \\
Perubahan SPL & Perubahan SPL & Cuaca & Iklim \\
Cuaca & $\mathbf{1}$ & & \\
Iklim & $-0,390$ & $\mathbf{0 , 8 2 2}$ & \\
\hline
\end{tabular}

Tabel 8. Nilai Akar AVE data bulanan

\begin{tabular}{lccc}
\hline \multicolumn{4}{c}{ Sebelum dieliminasi } \\
\hline Variabel & Perubahan SPL & Cuaca & Iklim \\
Perubahan SPL & $\mathbf{0 , 7 2 5}$ & & \\
Cuaca & $-0,364$ & $\mathbf{0 , 7 1 7}$ & \\
Iklim & 0,715 & $-0,075$ & $\mathbf{0 , 7 1 5}$ \\
\hline \multicolumn{4}{c}{ Setelah dieliminasi } \\
\hline Variabel & Perubahan SPL & Cuaca & Iklim \\
Perubahan SPL & $\mathbf{1}$ & & \\
Cuaca & $-0,277$ & $\mathbf{0 , 8 8 4}$ & \\
Iklim & 0,771 & 0,067 & $\mathbf{0 , 8 6 1}$ \\
\hline
\end{tabular}

Latan [14] dan Ghozali [9] mengungkapkan bahwa nilai akar kuadrat AVE yang lebih besar dari korelasi antar variabel latennya mengindikasikan bahwa indikator memiliki vailiditas diskriminan yang baik. Berdasarkan Tabel 7 dan 8 di atas dapat dikatakan hasil dari validitas diskriminan sudah baik dan memenuhi kriteria validitas diskriminan, setelah dilakukan eliminasi beberapa indikatorkarena nilai akar AVE lebih besar dari antar kontruksnya pada kedua data. Hal ini menunjukkan bahwa konstruk laten pada perubahan SPL, cuaca dan iklim mampu memprediksi indikator pengukur nya masing-masing lebih baik dibandingkan dengan indikator di variabel laten lainnya. Setelah uji validitas sudah terpenuhi, maka dilanjutkan dengan melakukan uji reliabilitas terhadap data yang digunakan. 
Tabel 9. Nilai Composite Reliability data harian

\begin{tabular}{lcccc}
\hline \multirow{2}{*}{ Variabel } & \multicolumn{2}{c}{ Data Harian } & \multicolumn{2}{c}{ Data Bulanan } \\
\cline { 2 - 5 } & $\begin{array}{l}\text { Sebelum } \\
\text { dieliminasi }\end{array}$ & $\begin{array}{l}\text { Setelah } \\
\text { dieleminasi }\end{array}$ & $\begin{array}{l}\text { Sebelum } \\
\text { dieliminasi }\end{array}$ & $\begin{array}{l}\text { Setelah } \\
\text { dieleminasi }\end{array}$ \\
\hline Perubahan & 0,002 & 1 & 0,075 & 1 \\
SPL & 0,672 & 0,806 & 0,642 & 0,877 \\
Cuaca & 0,696 & 0,775 & 0,74 & 0,85 \\
Iklim & & & & \\
\hline
\end{tabular}

Berdasarkan nilai composite reliability yang disajikan dalam Tabel 9, menunjukkan bahwa indikator yang telah ditetapkan mampu mengukur setiap variabel laten dengan baik. Dimana suhu permukaan laut mampu mengukur perubahan SPL, kecepatan angin dan kelembaban relatif dapat mengukur cuaca serta suhu udara dan radiasi matahari gelombang pendek pada data harian dan radiasi matahari gelombang panjang untuk data bulanan dapat mengukur iklim, atau dapat dikatakan bahwa outer model yang diperoleh telah reliabel.

\subsubsection{Evaluasi Inner Model}

Inner model adalah model yang menggambarkan hubungan antar variabel laten yang dievaluasi menggunakan koefisien jalur, $R^{2}, f^{2}$, dan $Q^{2}$. Inner model yang terbentuk ditampilkan pada Tabel 10.

Tabel 10. Inner model data

\begin{tabular}{c}
$\frac{\text { Data Harian }}{\text { Perubahan SPL }=}-0,285$ cuaca $+0,650 \mathrm{iklim}+\zeta$ \\
\hline Data Bulanan \\
\hline Perubahan SPL $=-0,330$ cuaca $+0,793 \mathrm{iklim}+\zeta$ \\
\hline
\end{tabular}

Model tersebut menunjukkan pada data harian dan bulanan bahwa Inner model yang didapatkan pada data bulanan variabel laten cuaca dan iklim memberikan pengaruh yang lebih besar dibandingkan dengan data harian. Nilai $R^{2}$ yang didapatkan tersebut digunakan untuk menjelaskan keragaman yang dapat dijelaskan variabel laten eksgogen terhadap variabel laten endogen.

Tabel 11. Nilai Rsquare data

\begin{tabular}{cc}
\hline Data Harian & Data Bulanan \\
\hline 0,563 & 0,704 \\
\hline
\end{tabular}

Tabel 11 menunjukkan bahwa pada data harian, variabel laten cuaca dan iklim dengan indikator pengukurnya dapat menjelaskan keragaman variabel laten perubahan SPL sebesar 56,3\% sedangkan pada data bulanan sebesar 70,4\% dapat dijelaskan oleh variabel laten cuaca dan iklim. Hal ini menunjukkan bahwa bahwa pada data bulanan nilai Rsquare yang diperoleh lebih baik dibandingkan pada data harian yang berarti keragaman yang dapat dijelaskan oleh cuaca dan iklim lebih besar terhadap perubahan SPL. Nilai $f$-square digunakan untuk mengukur pengaruh suatu variabel laten eksogen terhadap variabel laten endogennya. Terdapat kategori $f^{2}$ yaitu $\mathrm{f}^{2} \geq 0,35$ (kuat), $0,15 \leq \mathrm{f}^{2}<$ 
0,35 (medium), 0,02 $\leq \mathrm{f}^{2}<0,15$ (lemah), $f^{2}<0,02$ (tidak ada efek) [15]. Berikut nilai fsquare yang diperoleh pada Tabel 12.

Tabel 12. Nilai Fsquare data

\begin{tabular}{lcccc}
\hline & \multicolumn{2}{c}{ Data Harian } & \multicolumn{2}{c}{ Data Bulanan } \\
\hline & $\begin{array}{c}\text { Perubahan } \\
\text { SPL }\end{array}$ & Keterangan & $\begin{array}{c}\text { Perubahan } \\
\text { SPL }\end{array}$ & Keterangan \\
\hline Cuaca & 0,182 & Medium & 0,366 & Kuat \\
Iklim & 0,942 & Kuat & 2,114 & Kuat \\
\hline
\end{tabular}

Berdasarkan Tabel 12 pada data harian cuaca memiliki pengaruh yang medium sedangkan pada data bulanan memiliki pengaruh kuat. Sedangkan iklim memiliki pengaruh kuat terhadap perubahan SPL untuk data harian. Sedangkan pada data bulanan, cuaca dan iklim yang telah diwakili dengan beberapa indikatornya memiliki pengaruh yang kuat terhadap perubahan SPL.

Evaluasi inner model menggunakan $Q$-square $\left(Q^{2}\right)$. Jika $Q^{2}$ yang diperoleh $>0,5$ model dikatakan memiliki tingkat predictive relevance yang baik [7]. Nilai diperoleh melalui perhitungan manual disajikan pada Tabel 13.

Tabel 13. Nilai Qsquare data

\begin{tabular}{|c|c|}
\hline Data Harian & Data Bulanan \\
\hline $\begin{aligned} Q^{2} & =1-\left(1-R^{2}\right) \\
& =1-(1-0,563) \\
& =1-0,437 \\
& =0,563\end{aligned}$ & $\begin{aligned} Q^{2} & =1-\left(1-R^{2}\right) \\
& =1-(1-0,704) \\
& =1-0,296 \\
& =0,704\end{aligned}$ \\
\hline
\end{tabular}

Berdasarkan perhitungan tersebut didapatkan nilai $Q^{2}$ perubahan SPL pada data harian dan bulanan adalah 0,563 dan 0,704 yang nilainya lebih besar dari 0.5. Hal ini menunjukkan bahwa model memiliki predictive relevansi yang baik. Sehingga dapat dinyatakan model struktural juga cocok dengan data. Namun, data bulanan memiliki nilai predictive relevance yang lebih besar dibandingkan dengan data harian, yang artinya pada data bulanan, model yang didapatkan lebih baik.

\subsubsection{Pengujian Hipotesis}

Prosedur bootstrapping digunakan subsampel sebesar 1514 pada data harian dan 56 untuk data bulanan dengan $\alpha=0.05$, dimana nilai $t_{\text {tabel }}$ nya adalah 1,961 dan 2,003. Pada bootstrap dibuat $p$ seudo data (data bayangan) menggunakan informasi dan sifat-sifat dari data asli, sehingga data bayangan memiliki karakteristik yang mirip dengan data asli [16]. Kriteria pengujian hipotesis pada model pengukuran dan struktural ialah tolak hipotesis nol jika nilai mutlak $t_{\text {hitung }}>t_{\text {tabel. }}$. Artinya bahwa indikator-indikator tersebut signifikan serta mampu mengukur dan menjelaskan variabel laten. Pada inner model artinya, variabel laten eksogen tersebut mempunyai pengaruh yang signifikan terhadap variabel laten endogen. Selanjutnya, indikator yang bepengaruh signifikan terhadap variabel laten dapat dianalisis dengan menggunakan nilai $t$-statistik sebagaimana disajikan pada Tabel 14. 
Tabel 14. Nilai $t$-statistik outer model

\begin{tabular}{lcccc}
\hline & \multicolumn{2}{c}{ Data Harian } & \multicolumn{2}{c}{ Data Bulanan } \\
\hline & T statistics & P values & T statistics & Pvalues \\
\hline X2 <- Cuaca & 56,817 & 0 & 13,424 & 0 \\
X3 <- Cuaca & 32,102 & 0 & 7,439 & 0 \\
X4 <- Iklim & 244,582 & 0 & 64,523 & 0 \\
X5 <- Iklim & 18,520 & 0 & - & - \\
X6 <- Iklim & - & - & 11,603 & 0 \\
\hline
\end{tabular}

Berdasarkan Tabel 14 dapat dilihat bahwa indikator yang bepengaruh signifikan terhadap variabel laten cuaca adalah kecepatan angin dan kelembaban relatif. Sedangkan pada variabel laten iklim indikator yang signifikan yaitu suhu udara dan radiasi matahari gelombang pendek untuk data harian dan radiasi matahari gelombang panjang untuk data bulanan. Artinya, pada tiap-tiap variabel laten cuaca dan iklim dapat diukur menggunakan indikator tersebut.

Tabel 15. Nilai koefesien jalur Inner model

\begin{tabular}{lccccc}
\hline & \multicolumn{2}{c}{ Data Harian } & \multicolumn{2}{c}{ Data Bulanan } & \\
\hline & Koefisien & $t$ & Koefisien & $t$ & P \\
& Path & statistics & Path & statistics & Values \\
\hline Cuaca -> perubahan SPL & $-0,285$ & 17,541 & $-0,33$ & 4,246 & $0^{*}$ \\
Iklim -> perubahan SPL & 0,650 & 39,566 & 0,793 & 15,503 & $0^{*}$ \\
\hline
\end{tabular}

Berdasarkan Tabel 15 dapat dilihat bahwa indikator yang bepengaruh signifikan terhadap variabel laten cuaca dan variabel laten iklim pada taraf signifikansi (5\%). Nilai dari koefisien parameter jalur yang didapatkan dari hubungan antar variabel cuaca dengan perubahan SPL pada data harian sebesar $-0,285$ dan pada data bulanan sebesar $-0,33$ dengan nilai $t_{- \text {statistik }}>\mathrm{t}$-tabel $_{\text {tab }}$ pada taraf signifikansi (5\%). Sehingga terdapat pengaruh yang signifikan antara cuaca dengan perubahan SPL. Nilai negatif pada koefisien parameter artinya adalah semakin baik cuaca maka pengukur perubahan SPL yaitu suhu permukaan laut juga akan menurun. Nilai koefisien parameter jalur yang diperoleh dari hubungan antar variabel iklim dengan perubahan SPL pada data harian sebesar 0,650 dan pada data bulanan sebesar 0,793. Nilai positif pada koefisien parameter artinya adalah semakin baik iklim maka pengukur perubahan SPL yaitu suhu permukaan laut juga akan meningkat.

\section{Kesimpulan}

Dari sembilan indikator yang digunakan hanya terdapat 6 indikator yang signifikan yang memiliki nilai loading factor $>0,7$ yaitu suhu permukaan laut $\left({ }^{\circ} \mathrm{C}\right)$ sebagai pengukur variabel laten Perubahan SPL, kecepatan angin(m/s) dan kelembaban relatif (\%) sebagai pengukur variabel laten cuaca, dan suhu udara $\left({ }^{\circ} \mathrm{C}\right)$, radiasi matahari gelombang pendek $\left(\mathrm{w} / \mathrm{m}^{2}\right)$, dan radiasi matahari gelombang panjang $\left(\mathrm{w} / \mathrm{m}^{2}\right)$ sebagai pengukur variabel laten iklim. Variabel laten yang bepengaruh signifikan terhadap perubahan SPL ialah cuaca dan iklim.Inner model yang diperoleh pada data harian:Perubahan SPL ( $)=$ $-0,285$ cuaca $+0,650$ iklim $+\zeta$ dan pada data bulanan Perubahan SPL $(\eta)=-0,330$ cuaca + $0,793 \mathrm{iklim}+\zeta$. Model tersebut menunjukkan bahwa semakin baik keadaan cuaca maka 
perubahan SPL akan menurun sedangkan semakin baik keadaan iklim maka perubahan SPL juga akan meningkat. Pada data bulanan variabel laten cuaca dan iklim beserta indikator pengukurnya memberikan pengaruh yang lebih besar terhadap perubahan SPL dengan nilai koefesien pada model yang didapatkan lebih besar dibandingkan pada data harian. Nilai kriteria pada outer model dan inner model dengan data harian dan bulanan didapatkan hasil yang lebih baik pada data bulanan. Hal ini dapat disebabkan karena pada data bulanan memiliki jumlah data hilang yang lebih sedikit dan range datanya lebih kecil.

\section{Referensi}

[1] W. R. Reynolds, A. N. Rayner, M. T. Smith, C. D. Stokes, and W. Wang, "An improved in situ and satellite SST analysis for climate," Journal of climate., vol. 15, no. 13, pp. 1609-1625, 2002.

[2] J. Julismin, “Dampak dan Perubahan Iklim di Indonesia," Jurnal Geografi., vol. 5, no.1, pp. 39-46, 2013.

[3] D. M. Syaifullah, "Suhu Permukaan Laut Perairan Indonesia dan Hubungannya dengan Pemanasan Global," Jurnal Segara., vol. 11, no. 2, pp. 103-113, 2015.

[4] A. D. B. Nugroho, "Relationships between Sea Surface Temperature (SST) and rainfall distribution pattern in South-Central Java, Indonesia," Indonesian Journal of Geography., vol. 47, no.1, pp. 20-25, 2015.

[5] L. Zahroh, and M. B. Sujoko, "Analisa suhu permukaan laut untuk penentuan daerah potensi ikan menggunakan citra satelit modis level 1B," J. Teknik ITS., vol. 5, no. 2, pp. A846-A849, 2016.

[6] S. Haryono, and P. Wardoyo, Structural equation modelling, Bekasi: PT Intermedia Personalia Utama, 2012.

[7] M. Hijrah, B. Susetyo, and B. Sartono, "Structural equation modeling of national standard education of vocational high school using partial least square path modeling" International Journal of Scientific Research in Science Engineering and Technology, 2018, pp. 1418-1422.

[8] H. Kurniawan, "Partial Least Square (PLS) Sebagai Metode Alternatif SEM Berbasis Varians (LISREL) dalam Eksplorasi Data Survey dan Data Mining," Jurnal Telematika, vol. 7, no. 1, pp. 3-6, 2011.

[9] I. Ghozali, Structural Equation Modeling Metode Alternatif dengan Partial Least Square (PLS) Dilengkapi Software SmartPLS 3.00 Xistat 2014 dan WarpPLS 4.0, Edisi ke-4. Semarang: Badan Penerbit Universitas Diponegoro Semarang, 2014.

[10] J.F. Hair, CM. Ringle, M. Sarstedt, "PLS-SEM: Indeed a silver bullet," Journal of Marketing Theory and Practice, vol. 19, no. 2, pp. 139-151, 2011.

[11] WW. Chin, "How to write up and report PLS analyses", In Vinzi VE, WW. Chin, J. Henseler, H. Wang, "Handbook of Partial Least Squares: Concepts, Methods, and application," Vinzi VE, WW. Chin, J. Henseler, H. Wang. Jerman, pp. 645-689. Springer, 2010. 
[12] N. U. E. Sholiha, "(Structural equation modeling-partial least square untuk pemodelan derajat kesehatan kabupaten/kota di Jawa Timur (studi kasus data indeks pembangunan kesehatan masyarakat Jawa Timur 2013)", Institut Teknologi Sepuluh Nopember, 2015.

[13] S. Yamin, dan H. Kurniawan, Regresi dan Korelasi Dalam Genggaman Anda. Jakarta: Penerbit Salemba Empat, 2011.

[14] H. Latan, Model Persamaan Struktural Teori dan Implementasi AMOS 21.0, Bandung: Alfabeta, 2013.

[15] N. S. Akalili, “Analisis Pengaruh Tenaga Penjualan (Marketer) terhadap Kepuasan dan Pengaruh Kepuasan terhadap Rekomendasi di Perumahan "X" dengan Metode Structural Equation Modeling-Partial Least Square," ITS Surabaya, 2014.

[16] S. Akter, P. Ray, and J. D'Ambra, "An evaluation of PLS based complex models: The roles of Power Analysis, Predictive Relevance and GOF index," in Proceedings of the 17th Americas Conference on Information Systems (AMCIS2011) Detroit.USA, 2017, pp. 1-7.

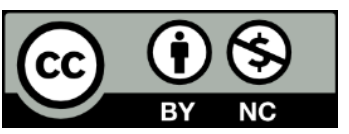

This article is an open-access article distributed under the terms and conditions of the Creative Commons Attribution-NonCommercial 4.0 International License. Editorial of JJoM: Department of Mathematics, Universitas Negeri Gorontalo, Jln. Prof. Dr. Ing. B.J. Habibie, Moutong, Tilongkabila, Kabupaten Bone Bolango, Provinsi Gorontalo 96119, Indonesia. 